\title{
HUBUNGAN ANTARA PENGUASAAN KOSAKATA DENGAN KEMAMPUAN MENULIS CATATAN HARIAN PADA SISWA KELAS VII MTS MATHLA'UL ANWAR PUSAT MENES KABUPATEN PANDEGLANG
}

\author{
RELATIONSHIP BETWEEN THE VOCATIONAL POWER OF VOCATIONAL \\ SCHOOL AND DAILY WRITING ABILITY IN CLASS VII STUDENTS MATHLA'UL \\ ANWAR CENTER OF MENES CENTER OF PANDEGLANG DISTRICT
}

\author{
ADE JUANTO \\ Sekolah Tinggi Keguruan dan IImu Pendidikan Syekh Manshur \\ Jalan Raya Labuan Km 5 Kadulisung Pandeglang \\ Ponsel: 085219540775 \\ Surel: adejuanto7@gmail.com
}

\begin{abstract}
Abstrak
Salah satu bentuk kemampuan berkomunikasi secara lisan tersebut bisa dituangkan dalam bentuk kemampuan dalam penguasaan kosakata. Kosakata merupakan suatu bentuk kata dalam suatu bahasa, baik yang dikenal (dikuasai) atau yang belum dikenal (belum dikuasai). Tujuan dalam penelitian ini adalah untuk mengetahui adanya hubungan penguasaan kosakata dengan kemampuan menulis catatan harian pada siswa kelas VII MTs Mathla'ul Anwar Pusat Menes Tahun Pelajaran Kabupaten Pandeglang. Untuk mengetahui kekuatan perbandingan digunakan uji hipotesis dan diperoleh harga $t_{\text {hitung }}=19,8$ dengan taraf signifikan $\alpha=$ $5 \%$ dan derajat kebebasan $(\mathrm{dk})=30-2=28$ diperoleh $t_{\text {tabel }} 1,71$. Karena $t_{\text {hitung }}>t_{\text {tabel, }}$ artinya tolak $H_{0}$, yang menyatakan bahwa terdapat hubungan antara penguasaan kosakata dengan kemampuan menulis catatan harian pada siswa kelas VII MTs Mathla'ul Anwar Pusat Menes Kabupaten Pandeglang.
\end{abstract}

Kata kunci : Penguasaan Kosakata, Menulis Catatan Harian.

\section{Abstract}

One form of the ability to communicate verbally can be expressed in the form of vocabulary mastery. Vocabulary is a form of words in a language, either known (mastered) or unknown (not mastered). The purpose of this study was to determine the relationship between vocabulary mastery and the ability to write daily notes in class VII students of MTs Mathla'ul Anwar Pusat Menes Academic Year, Pandeglang Regency. To determine the strength of the comparison, a hypothesis test was used and the value of tcount $=19.8$ was obtained with a significant level of $\alpha=5 \%$ and degrees of freedom $(d k)=30-2=28$, obtained t table 1.71. Because tcount> ttabel, it means reject Ho, which states that there is a relationship between vocabulary mastery and the ability to write daily notes in class VII students of MTs Mathla'ul Anwar Pusat Menes, Pandeglang Regency.

Keywords: Vocabulary Mastery, Writing Daily Notes. 
PENDAHULUAN

Keterampilan

menulis merupakan suatu keterampilan berbahasa yang dipergunakan untuk berkomunikasi secara tidak langsung, tidak secara tatap muka dengan orang lain. Menulis merupakan suatu kegiatan yang produktif dan ekspresif. Dalam kegiatan menulis ini, penulis haruslah terampil memanfaatkan grafologi, struktur bahasa, dan kosakata. Keterampilan menulis tidak akan datang secara otomatis, tetapi harus melalui latihan dan Pratik yang banyak dan teratur. Dalam kehidupan modern ini, jelas bahwa keterampilan menulis sangat dibutuhkan. Kiranya tidak terlalu berlebihan bila kita katakan bahwa keterampilan menulis merupakan suatu ciri dari orang yang terpelajar atau bangsa yang terpelajar.

Ketidakmampuan siswa dalam penguasaan aspek kosakata akan sangat menghambat dalam menulis sebuah catatan harian. Jika pemahaman tentang menulis kurang dikuasai, maka siswa menjadi tidak paham terhadap bagaimana kelengkapan dalam menulis (catatan harian). Efek selanjutnya maka siswa tidak memahami terhadap penguasaan kosakata dalam menulis (catatan harian).
Suatu solusi dalam upaya menangani masalah tersebut adalah melakukan pengkajian secara akurat melalui kegiatan penelitian tentang kemampuan menulis catatan harian yang akan dihubungkan dengan penguasaan kosakata. Kemampuan menulis yang dimaksud adalah kemampuan menulis catatan harian.

Atas dasar alasan-alasan yang telah dikemukakan maka peneliti tertarik untuk melakukan penelitian. maka penelitian ini mengambil judul “ Hubungan antara penguasaan Kosakata dengan Kemampuan Menulis Catatan Harian pada Siswa Kelas VII MTs. Mathla'ul Anwar Pusat Menes Kabupaten Pandeglang “.

\section{KAJIAN TEORITIK}

$$
\text { Kemampuan menulis }
$$

merupakan perwujudan bentuk komunikasi secara tidak langsung, tidak langsung bertatap muka dengan orang lain. Menulis merupakan suatu kegiatan yang produktif dan ekspresif. Pada kenyataannya menulis merupakan keterampilan yang dapat dikatakan lebih sulit dari pada keterampilan berbahasa yang lain, seperti menyimak, membaca dan berbicara. Dalam proses menulis, dituntut agar memperhatikan struktur yang berkaitan dengan unsur-unsur 
tulisan agar pembaca dapat memahami pesan yang ingin disampaikan oleh penulis. Oleh karena itu, penulis harus benar-benar menggunakan atau memakai struktur sebuah tulisan seperti kata, kalimat, paragraf, dan lain-lain dengan baik. Menurut Tarigan (2008:22), menulis ialah menurunkan atau melukiskan lambang-lambang atau grafik yang menggambarkan suatu bahasa yang dipahami oleh seseorang sehingga seseorang atau orang lain dapat membaca lambang-lambang grafik tersebut kalau mereka memahami bahasa dan gambaran grafik itu.

Menulis adalah kegiatan sekaligus keterampilan yang terintegrasi, bahkan menulis selalu ada dalam setiap pembelajaran, sama halnya dengan membaca. Memiliki kemampuan menulis yang baik bukan karena harus menjadi penulis, tetapi karena kita wajib terampil dalam berkomunikasi dengan bahasa lisan dan tulisan (Zaenurrahman, 2013:186).

Suparno dan Yunus (2008:1), mengatakan bahwa menulis yaitu suatu kegiatan penyampaian pesan (komunikasi) dengan menggunakan bahasa tulis sebagai alat atau medianya. Selain itu, Semi (2007:14), menyatakan bahwa dalam bukunya pengertian menulis adalah suatu proses kreatif memindahkan gagasan ke dalam lambang-lambang tulisan.

Menurut KBBI (2001:1219), pengertian menulis adalah melahirkan pikiran atau perasaan (seperti mengarang, membuat surat) dengan tulisan. Menulis berarti menuangkan isi hati si penulis ke dalam bentuk tulisan, sehingga maksud hati penulis bisa diketahui banyak orang orang melalui tulisan yang dituliskan.

Berdasarkan uraian di atas dapat disimpulkan bahwa menulis adalah suatu kemampuan seseorang untuk mengungkapkan gagasan, pikiran, pengetahuan dan pengalaman-pengalaman hidupnya melalui bahasa tulis yang jelas sehingga pembaca mengerti apa yang dimaksud penulis.

Catatan harian, dalam bahasa Inggris disebut diary atau bisa disebut juga dengan buku harian, berisi halhal penting yang terjadi pada hari itu. Hal penting itu dapat berupa pengalaman menarik yang bermanfaat dapat dituliskan didalamnya. Pemikiran yang muncul, yang dianggap penting dan bermanfaat, juga dapat direkam dalam catatan harian. Jadi, catatan harian pada dasarnya adalah catatan penting. 
Hidup adalah pengalaman semakin lama orang hidup semakin banyak pengalaman yang diperoleh.. Membaca hal-hal yang telah kita tulis mengenai pengalaman masa lalu maupun yang sedang dialami. Menurut Tarigan (2008:31) Catatan harian adalah suatu bentuk tulisan yang memberikan sesuatu yang paling menyenangkan tentang pengalaman, pemikiran, dan perasaan yang ditulis setiap hari oleh seseorang, dalam penjelajahan diri pribadi sang penulis.

Catatan harian memiliki dua kategori. Pertama, catatan harian yang bersifat personal atau individu atau pribadi. Catatan harian ini menjadi milik individu. Catatan harian jenis ini dibuat, dibaca, dan dimanfaatkan oleh individu. Isinya berkaitan dengan masalah-masalah pribadi. Oleh karena itu, orang lain tidak boleh membacanya. Kedua, buku harian yang bersifat umum. Catatan harian ini biasanya menjadi milik suatu lembaga. Catatan harian jenis ini dibuat, dibaca, dan dimanfaatkan oleh atau atas nama lembaga. Kedua jenis catatan harian ini dapat ditemukan dalam kehidupan sehari-hari. (Zulkarnaini, 1996:1).

Sebelum menulis catatan harian ada beberapa hal yang harus diketahui. Hal itu adalah komponen atau elemen catatan harian, format catatan harian, dan penggunaan bahasa dalam catatan harian. Elemen minimal catatan harian ada dua. Pertama komponen hari, tanggal, dan tahun. Kedua, komponen isi catatan harian. Oleh karena format catatan harian dapat di buat seperti dalam tabel di bawah ini.

Format alternatif 1

\begin{tabular}{|c|c|}
\hline $\begin{array}{c}\text { Hari dan } \\
\text { Tanggal, } \\
\text { Tahun }\end{array}$ & Isi Catatan Harian \\
\hline & \\
& \\
& \\
\hline
\end{tabular}

Format alternatif 2

\section{Hari dan Tanggal, Tahun Isi Catatan Harian}

Format-format di atas dapat diciptakan sendiri. Sebenarnya tidak 
ada acuan format yang standar untuk catatan harian. Artinya format catatan harian dapat ditentukan oleh pemiliknya.

Selain itu, suparno dan Yunus (2008:14) mengatakan bahwa pendekatan menulis dibagi menjadi 4 adalah:

1. Pendekatan

frekuensi, menyatakan bahwa banyaknya latihan mengarang sekalipun tidak dikoreksi ( seperti buku harian atau surat), akan membantu meningkatkan keterampilan menulis seseorang.

2. Pendekatan gramatikal, bahwa pengetahuan orang mengenai struktur bahasa akan mempercepat kemahiran orang dalam menulis

3. Pendekatan koreksi, bahwa seseorang menjadi penulis karena dia menerima banyak koreksi atau masukan yang diperoleh atas tulisannya.

4. Pendekatan

formal, mengungkapkan bahwa keterampilan menulis akan diperoleh bila pengetahuan bahasa, pengalineaan, pewacanaan, serta konvensi atau aturan penulisan dikuasai dengan baik.
Berdasarkan uraian di atas, maka yang dimaksud dengan kemampuan menulis catatan harian adalah berisi hal-hal penting yang terjadi pada hari itu. Hal penting itu dapat berupa pengalaman, pemikiran, dan perasaan yang dituliskan setiap hari.

Menurut KBBI (2003:597) kosakata adalah perbendaharaan kata atau banyaknya kata-kata yang dimiliki suatu bahasa. Pendapat ini sesuai dengan pendapat yang dikemukakan oleh Tarigan (2001:197) bahwa "Kosakata adalah kata-kata yang merupakan perbendaharaan suatu bahasa.

Penguasaan kosakata memegang peranan paling penting dalam hidup dan kehidupan manusia. Penguasaan kosakata menjadi ukuran tingkat intelektualitas seseorang dan tingkat peradaban sebuah bangsa.

Kridalaksana

(2001:122) memberikan pengertian yang sama antara pengertian kosakata dengan leksikon (Vocabulary). Selanjutnya dikatakan bahwa pengertian leksikon adalah (1) komponen bahasa yang memuat semua informasi tentang makna dan pemakaian kata dalam bahasa; (2) kekayaan kata yang dimilliki seorang pemmbicara, penulis, atau suatu bahasa; (3) daftar kata 
yang disusun seperti kamus, tetapi dengan penjelasan singkat dan praktis.

Pengertian-pengertian tentang kosakata di atas memberikan dasar yang kuat untuk menyimpulkan tentang pengertian kosakata. Jadi yang dimaksud dengan kosakata adalah perbendaharaan kata atau sejumlah kata dalam bahasa yang lengkap dengan makna dan pemakainnya. Sedangkan kosakata yang ada dalam seseorang adalah kekayaan kata yang dimiliki seseorang dalam penguasaan berbahasa, sehingga memiliki kemampuan untuk memiliki makna dan kemampuan menggunakan dalam situasi lisan maupun situasi tulisan.

\section{METODE PENELITIAN}

Penelitian ini bertujuan untuk mengetahui hubungan penguasaan kosakata dengan kemampuan menulis catatan harian siswa. Dalam penelitian ini terdapat dua variabel yaitu penguasaan kosakata sebagai variabel terikat, dan kemampuan menulis catatan harian sebagai variabel bebas.

Penelitian dilaksanakan pada semester ganjil Tahun Pelajaran 2018/2019 selama kurang lebih dua
Minggu. Penelitian dilaksanakan di MTs Mathla'ul Anwar Pusat Menes Kabupaten Pandeglang Provinsi Banten.

Populasi dari penelitian ini adalah seluruh siswa kelas VII MTs Mathla'ul Anwar Pusat Tahun Pelajaran 2014/2015.

Tabel

\section{Populasi Siswa Kelas VII MTs}

Mathla'ul Anwar Pusat Menes

Tahun Pelajaran 2018/2019

\begin{tabular}{|c|c|c|}
\hline No & Kelas & Jumlah \\
\hline 1. & KMA & 26 \\
\hline 2. & VII A & 30 \\
\hline 3. & VII B & 30 \\
\hline 4. & VII C & 30 \\
\hline 5. & VII D & 25 \\
\hline 6. & VII E & 19 \\
\hline
\end{tabular}

Teknik pengambilan sampel dilakukan dengan menggunakan teknik cluster random sampling.

Teknik ini digunakan karena memperhatikan ciri-ciri antara lain siswa mendapat materi berdasarkan kurikulum yang sama, dan penempatan siswa tidak berdasarkan rangking. Selanjutnya kelas yang terpilih dengan menggunakan teknik caluster random sampling yaitu kelas VII A yang sampelnya 30 orang. 


\section{HASIL DAN PEMBAHASAN}

1. Data Tentang Skor Penguasaan Kosakata Pada Siswa Kelas VII MTs Mathla'ul Anwar Pusat Menes Tahun Pelajaran 2014/2015, secara teoritis mempunyai skor terendah 0 dan skor tertinggi 100. berdasarkan data hasil penelitian diperoleh skor terendah 60 , skor tertinggi 88 , dan skor rentangan 28 . selain itu diperoleh modus 76,85 mean (rata-rata) 75,27 ,median 76,17 dan standar deviasi 6,35.

2. Data Tentang Skor Kemampuan Menulis catatan Harian Pada Siswa Kelas VII MTs Mathla'ul Anwar Pusat Menes Tahun Pelajaran 2014/2015. secara teoritis mempunyai skor terendah 0 dan skor tertinggi 60 . berdasarkan data hasil penelitian diperoleh skor terendah 60 , skor tertinggi 85 , dan skor rentangan 25. selain itu diperoleh modus 77,14 , mean (rata-rata) 73,54, median 74,95 , standar deviasi $6 ; 32$.
Berdasarkan hasil pengujian hipotesis yang menunjukan $t_{\text {hitung }}=$ 19,8.< Ttabel dengan dk 28.dan taraf signifikansi $5 \%=1,71$ maka Ho ditolak dan $\mathrm{Hi}$ diterima. Hal ini berarti berarti hipotesis kerja yang menyatakan "Terdapat hubungan positif penguasaan kosakata dengan kemampuan menulis catatan harian pada siswa kelas VII MTs Mathla'ul Anwar Pusat Menes Tahun Pelajaran 2018/2019 " dapat diterima. Dengan demikian penguasaan kosakata mempunyai hubungan yang signifikan dalam meningkatkan kemampuan menulis catatan harian.

\section{SIMPULAN}

Berdasarkan hasil penelitian yang dilakukan di Madrasah Tsanawiyah Mathla'ul Anwar Pusat Menes mengenai Hubungan Antara Penguasaan Kosakata dengan Kemampuan Menulis Catatan Harian, diperoleh kesimpulan sebagai: berikut penguasaan kosakata, berdasarkan data hasil penelitian diperoleh skor terendah 60 , skor tertinggi 88 , dan skor rentangan 28. selain itu diperoleh modus 76,85 mean (rata-rata) 75,27 ,median 76,17 dan standar deviasi 6,35. Sedangkan kemampun menulis catatan harian, berdasarkan data hasil penelitian diperoleh skor 
terendah 60 , skor tertinggi 85 , dan skor rentangan 25 . selain itu diperoleh modus 77,14 , mean (rata-rata) 73,54 , median 74,95, standar deviasi 6;32.

Dari hasil pengujian hipotesis dengan taraf signifikan $\alpha=0,05$ diperoleh. $t_{\text {hitung }} 19,8$ sedangkan $t_{\text {tabel }}$ dengan derajat kebebasan 28 adalah 1,71 dari hasil data diatas, maka dapat disimpulkan bahwa penguasaan kosakata dengan kemampuan menulis catatan harian lebih baik.

\section{DAFTAR PUSTAKA}

Arikunto,S. Prosedur penenlitian suatu pendekatan praktek. Edisi revisi VI. Jakarta: Rineka cipta, 2003.

Depdikbud. Kurikulum. 2006. Standar Kompetensi Mata Pelajaran Bahasa dan Sastra Indonesia Sekolah Menengah Pertama dan Madrasah Tsanawiyah. Jakarta, 2006

Kridalaksana a, Harimurti. Kamus Linguistik. Jakarta: PT Gramedia, 2001

Kartimi, Tiem. Perencanaan Menulis Karangan. Bogor: Universitas Pakuan, 2006.

Kamus Besar Bahasa Indonesia. Balai Pustaka, Jakarta,2001.
Kerat, Gorys. Kompopsisi. EndeFlores: Nusa Indah, 1980.

Margono, S. Metodologi penelitian pendidikan. Jakarta: Rineka cipta, 2005.

Parera, Jos Daniel. Belajar Mengemukakan Pendapat. Jakarta: Erlangga,1991.

Riduwan dan Akdon. Rumus dan Data Analisis Statistika. Bandung : Alfabeta, 2013.

Riduwan. Dasar-dasar Statistika. Bandung : Alfabeta, 2011.

Sugiyono. Statistika Untuk Penelitian. Bandung : Alfabeta, 2010.

Suparno dan Yunus. Keterempilan Dasar Menulis. Jakarta: Universitas Terbuka, 2008.

Sudjana, Nana. Penilaian hasil proses belajar mengajar. Bandung: PT Remaja Rosdakarya, 2010. Tarigan, Henry Guntur. Menulis Sebagai Keterampilan Berbahasa. Bandung : Angkasa, 2008.

Zulkarnaini. Bermula dari Ide, Berakhir pada Tulisan. Bukittinggi, 1996.

Zainurrahman. Menulis Dari Teori Hingga Pratek. Bandung : Alfabeta, 2013. 